\title{
NUTRIENT COMPOSITION OF GRILLED COOKED PANGASIUS MEAT AND THEIR ANALYSIS OF PROXIMATE, FATTY ACID AND MINERAL COMPOSITION
}

\section{S. KOTHANDAPERUMAL}

Department of Fish Processing Technology, Thoothukudi, Schools of Post- Harvest Technology

ABSTRACT
The proposed research is to analyse the nutritional composition of heat treatment Pangasius meats. Catfish lipids are
low because of a small amount of n-3 family PUFA and a high amount of MUFA and SFA. The SFA and trans C18:1
MUFA can increase the risk of chronic cardiovascular diseases that affects the heart, blood vessels, and brain.
Effective processing method can get rid of the fat content in Pangasius catfish fillet and provide a good protein food for
consumers.
The present project is therefore proposed to develop a suitable preprocessing method for the removal of fat
The present research is proposed to study the proximate composition, fatty acid composition and minerals composition
of the raw and microwave defatted fillets.
KEYWORDS: Nutrient Composition of Grilled Cooked Pangasius Meat and their Analysis of Proximate, Fatty Acid
And Mineral Composition

Received: May 22, 2021; Accepted: Jun 12, 2021; Published: Jun 21, 2021; Paper Id.: IJASRDEC20217

\section{INTRODUCTION}

Pangasius genus includes the catfish varieties that are commonly found in the south-east Asian region. It belongs to the family Pangasiidae. The most common variety of cultured fish is Pangasianodon hypophthalmus. This fish species is also called, Sutchi catfish, striped catfish, or Tra fish. Among all the freshwater species, Pangasius catfish is the world's fastest-growing species in aquaculture. They are traded worldwide as skinless and boneless fillets popularly along with portions, steaks, fillets, and also as value-added products Jeyakumari et al., 2016; Thi et al., 2013). The fish attains a bodyweight of 1.2 to $1.3 \mathrm{~kg}$ rapidly within six months but usually harvested after eight months of culture. There is a tremendous demand for fish-based products, especially value-added products such as ready-to-eat "convenience" products. The filleting industry produces significant amounts of head, bone, scrap meat, and skin by-products. By way of proper processing, it can be converted to various high-value products, and it has good economic efficiency. The utilization of Pangasius fish waste is an excellent potential source for value-added products.Studies on the development of Pasta products from Pangasius fish are detailed below. Pangasius fillets are a good substitute for white-fleshed fishes in the market due to their increasing acceptability and popularity; Pangasius is usually served in the European market as skinned and boneless frozen fillets (Noseda et al., 2012), currently, these fillets exported to over 100 countries worldwide. Fillets were characterized by high moisture levels of $80 \%$ and low crude protein of $15.8 \%$ and lipid of $3.0 \%$ contents. Total lipids were characterized by low cholesterol levels of $40 \mathrm{mg} / 100 \mathrm{~g}$, high percentages of saturated fatty acids $(47.5 \%)$ of total fatty acid. Low percentages of polyunsaturated fatty acids $(20 \%)$ are present in total fatty acids mainly represented by linoleic acid 
(60\% of total polyunsaturated fatty acids).

The mineral composition was characterized by a high sodium content of about $595 \mathrm{mg} / 100 \mathrm{~g}$ (Domiszewski et al., 2011). The pasta is mainly prepared from wheat flour, which contains about $10-15 \mathrm{~g} / 100 \mathrm{~g}$ of protein but there is a lack of essential amino acids, making it an incomplete protein. To compensate for the lack of protein in the pasta, fish protein can serve as an excellent source of proteins as they contain all the essential amino acids with excellent digestibility and it is efficiently available at low cost. Pangasius is a majorly cultured freshwater fish species in India; it is a rich source of proteins and other nutrients. Pangasius fillet contains a considerable amount of rich fatty acids and proteins. This work is mainly focused on the study of nutritional composition such as proximate, fatty acid and mineral composition (Mahmoud et al., 2012).

\section{MATERIALS AND METHODS}

\subsection{Materials}

Pangasius hypophthalmus were collected from Madurai AM fish farm and fish markets. The collected fishes were kept in insulated iceboxes. Insulated icebox prevents dehydration, and temperature fluctuation thus delays the spoilage of fish. Further, it is easy to handle. Flake ice produced by flake ice machine was used during fish transportation and for processing purpose.

Size of the ice for 2-3 cm level were produced to kept into the box and fish were spread on ice layer then carried out further steps.

\subsection{Method}

\subsubsection{Sampling Procedure}

Randomly samples were chosen and analyzed for proximate, fatty acid composition(PUFA) and mineral composition. Samples were collected from raw fillets and grilled cooked meat.

\subsubsection{Proximate Composition Analysis}

The protein, fat, ash, water and carbohydrate content were analyzed by AOAC methods (2000). 1 gram wet sample need for analysis of protein content, 4.5-5 gram of samples are used to estimate of the fat content, 2 gram of dry sample are used to estimate of the ash and 10 gram of wet samples are used to analysis of the moisture content. The protein content of raw fillet, cooked meat and pasta product was analyzed by the Kjeldahl method (1883). The digester temperature was followed at 300 to $400^{\circ} \mathrm{C}$ and distillation process was run for 8 minutes. The fat content of raw fillet, cooked meat and pasta product was analysed by Folch methods (1957). The moisture content of raw meat, cooked meat and pasta products were analysed by AOAC methods (2000). The samples were kept in hot air oven for 12 hours at $100^{\circ} \mathrm{C}$. Ash content of raw meat, cooked meat and pasta products were analysed by AOAC methods (2000). The samples were kept in muffle furnace for 24 hours at $550^{\circ} \mathrm{C}$. The carbohydrate content of raw meat, cooked meat and pasta products were analysed by different methods.

The protein estimated chemicals are inclusion of sulfuric acid, digestion mixture: copper sulfate- $0.1 \mathrm{~g}$ and potassium sulfate- $2.5 \mathrm{~g}$ for each sample, sodium hydroxide, $40 \%$, boric acid, $4 \%$, mixed indicator: methyl red- $0.16 \mathrm{~g}$ and bromocresol green-80 mg in $100 \mathrm{ml}$ of $95 \%$ ethanol and standard sulfuric acid $0.1 \mathrm{~N}$. analyzed fat composition was used chemicals inclusion of chloroform and methanol (2:1) and potassium chloride(KCL), $0.74 \%$. and one more method of soxhlet used in $80 \mathrm{ml}$ of petroleum ether. crude fiber analyzed chemical inclusion of sulfuric acid $1.25 \%$ and sodium 
hydroxide $1.25 \%$ and petroleum ether $40-60^{\circ} \mathrm{C}$.

\subsubsection{Fatty Acid Aomposition Analysed by Gas Chromatography}

Fatty acids are a very important component of lipids content. GC is the most common method used for analysis of fatty acid composition. The fatty acid is a complex structure. It contains more components of fatty acid such as acylglycerols, cholesterol esters, waxes and glycsosphingolipds. It is extracted b saponification hydrolysis it is done by alkaline medium AOAC,1990. The FAMEs are extracted by use of the methanol and boron trifluoride. Extraction and methylation is done by folch method are used to obtained the lipid components from the ten gram of fish samples. Esterification was done, take $250 \mathrm{~g}$ lipid fraction it is dissolved into toluene in the round bottom flask. Then, added $4 \mathrm{ml}$ sodium hydroxide and reflux for 5-10minutes until droplets of fat disappear. added $5 \mathrm{ml}$ of methanol and reflux for another $1 \mathrm{~min}$. cool the content and add $15 \mathrm{ml}$ of saturated sodium chloride solution. then, add $5 \mathrm{ml}$ of hexane, shake well and then remove the upper layer hexane layer. Repeat the extraction with hexane twice. It combines hexane layer and evaporates to dryness in a rotary flask evaporator set at $55-60^{\circ} \mathrm{C}$. The methyl esters in $1 \mathrm{ml}$ of HPLC grade hexane for injection in GC. The column at $210^{\circ} \mathrm{C}$ for 30minutes. then, inject $0.5 \mathrm{ml}$ of standard FAMEs mixture onto the GC. Then, separation of FAMEs takes $45 \mathrm{~min}$.

Next, inject $0.5 \mathrm{ml}$ of sample FAMEs. Identify the individual fatty acid in the sample by comparing the retention time of the individual fatty acid in the standard mixture. calculated area unit value expressed to percentage of the fatty acid of total lipids.

\subsubsection{Mineral Composition Analysis}

Some vital macro and trace mineral content of raw meat, cooked meat, and pasta products was analysed by titrations methods. Titration methods were used to analyses samples. $\mathrm{Ca}, \mathrm{Mg}, \mathrm{Fe}, \mathrm{Zn}, \mathrm{Na}$ and $\mathrm{P}$ contents of raw and defatted meats. $\mathrm{Ca}, \mathrm{Mg}$ and $\mathrm{Zn}$ were analysed by EDTA titration method. sodium done by flame photometer, phosphorous was done by amino naphthol sulphonic acid and iron was done by 1:10 phenanthrolene.

Calculation: $(\mathrm{mg} / 100 \mathrm{~g})=\mathrm{T} . \mathrm{V} \times \mathrm{N} \times 100 \times \mathrm{D} . \mathrm{F} / \mathrm{W} \times 0.05$

\subsection{Statistical Analysis}

The SPPS 19 (IBM, 2O10) statistical package was used for the analysis of experimental results. The results were produced in the mean standard deviation.

\section{RESULT AND DISCUSSIONS}

\subsection{Proximate Composition of Raw and Defatted Pangasius Fillets}

Grill oven cooked methods of heat treatment used to remove the fat content of the fish fillets with minimal nutritional damage. The proximate composition of the raw, grill, methods were studied.

Those were estimated for the content of the moisture, protein, fat and ash, $72.12 \pm 0.68 \%, 21.52 \pm 0.60 \%$, $4.32 \pm 071 \%$ and $1.31 \pm 0.065 \%$ and $69.94 \pm 1.014 \%, 24.52 \pm 0.48 \%, 4.93 \pm 0.266 \%$ and $1.43 \pm 0.225 \%$ and $70.93 \pm 2.571 \%$, $23.85 \pm 0.911 \%, 3.87 \pm 1.036$ and $1.31 \pm 0.052 \%$ and $66.54 \pm 0.373 \%, 25.88 \pm 0.802 \%, 7.06 \pm 0.332$ and $1.53 \pm 0.141 \%$ was reported by Marimuthu et.al., 2011. This study was expressed after heat treatment and there was an increase in content of the protein, fat and ash and a decrease in moisture content which was reported by Erosy and Ozeren, 2009.

The present study the Pangasius fish fillets were used to remove the fat content, the fat content SFA and MUFA 
could be reduced or removed by use of the different heat treatment method such as the microwave, grilled and steam method. The proximate composition of the grill cooked fillets of the head, body, ventral and tail portions was estimated as moisture, protein, fat, ash and carbohydrate from head portion- $67.46 \%, 24.16 \%, 4.32 \%, 2.34 \%$ and $1.71 \%$, body portion$67.54 \%, 24.23 \%, 4.44 \%, 2.22 \%$ and $1.56 \%$, ventral region-67.15\%, $24.22 \%, 4.63 \%, 2.05 \%$ and $1.93 \%$ and tail portion$67.02 \%, 24.15 \%, 3.56 \%, 2.05 \%$ and $2.34 \%$. The proximate composition of the grilled cooked meat is found to be in the range of up to $98.65 \%$. The fat, moisture, protein, ash and carbohydrate content could be increased or decreased is based on the portion of meat. ANOVA test was applied to analyze the sample variation between the samples. Degrees of freedom 2. T-test was applied there is no significant difference between samples and F-test was applied there was little significant variation between samples. F- test not that much variation between the samples. $0.1 \%$ means only one percent changes from100 percentages of samples.

\section{Grilled Cooked Pangasius Head Portion}

Table 1: Proximate Composition of Pangasius Fillets

\begin{tabular}{|l|c|c|c|c|}
\hline \multicolumn{1}{|c|}{ Composition } & Sample-1 & Sample-2 & Sample-3 & Total/Average \\
\hline Moisture & $67.44 \%$ & $67.47 \%$ & $67.47 \%$ & $67.46 \pm 0.000$ \\
\hline Protein & $24.18 \%$ & $24.15 \%$ & $24.15 \%$ & $24.16 \pm 0.000 \%$ \\
\hline Fat & $4.31 \%$ & $4.36 \%$ & $4.31 \%$ & $4.32 \pm 0.000 \%$ \\
\hline Ash & $2.36 \%$ & $2.36 \%$ & $2.31 \%$ & $2.34 \pm 0.000 \%$ \\
\hline carbohydrate & $1.71 \%$ & $1.66 \%$ & $1.76 \%$ & $1.71 \pm 0.000 \%$ \\
\hline
\end{tabular}

Grilled Cooked Pangasius Body Portion

\begin{tabular}{|l|c|c|c|c|}
\hline Composition & Sample-1 & Sample-2 & Sample-3 & Total/Average \\
\hline Moisture & $67.57 \%$ & $67.53 \%$ & $67.53 \%$ & $67.54 \pm 0.000 \%$ \\
\hline Protein & $24.24 \%$ & $24.21 \%$ & $24.24 \%$ & $24.23 \pm 0.001 \%$ \\
\hline Fat & $4.43 \%$ & $4.45 \%$ & $4.45 \%$ & $4.44 \pm 0.000 \%$ \\
\hline Ash & $2.23 \%$ & $2.23 \%$ & $2.20 \%$ & $2.22 \pm 0.000 \%$ \\
\hline carbohydrate & $1.53 \%$ & $1.58 \%$ & $1.58 \%$ & $1.56 \pm 0.000 \%$ \\
\hline
\end{tabular}

Grilled Cooked Pangasius Ventral Portion

\begin{tabular}{|l|c|c|c|c|}
\hline Composition & Sample-1 & Sample-2 & Sample-3 & Total/Average \\
\hline Moisture & $67.12 \%$ & $67.17 \%$ & $67.17 \%$ & $67.15 \pm 0.000 \%$ \\
\hline Protein & $24.23 \%$ & $24.23 \%$ & $24.21 \%$ & $24.22 \pm 0.001 \%$ \\
\hline Fat & $4.65 \%$ & $4.62 \%$ & $4.62 \%$ & $4.63 \pm 0.000 \%$ \\
\hline Ash & $2.06 \%$ & $2.05 \%$ & $2.06 \%$ & $2.05 \pm 0.000 \%$ \\
\hline carbohydrate & $1.94 \%$ & $1.93 \%$ & $1.94 \%$ & $1.93 \pm 0.000 \%$ \\
\hline
\end{tabular}

Grilled cooked Pangasius Tail Portion:

\begin{tabular}{|l|c|c|c|c|}
\hline Composition & Sample-1 & Sample-2 & Sample-3 & Total/Average \\
\hline Moisture & $67.02 \%$ & $67.04 \%$ & $67.02 \%$ & $67.02 \pm 0.000 \%$ \\
\hline Protein & $24.14 \%$ & $24.14 \%$ & $24.18 \%$ & $24.15 \pm 0.001 \%$ \\
\hline Fat & $4.21 \%$ & $4.21 \%$ & $4.23 \%$ & $3.56 \pm 0.000 \%$ \\
\hline Ash & $2.23 \%$ & $2.27 \%$ & $2.27 \%$ & $2.25 \pm 0.000 \%$ \\
\hline carbohydrate & $2.40 \%$ & $2.34 \%$ & $2.30 \%$ & $2.34 \pm 0.000 \%$ \\
\hline
\end{tabular}




\begin{tabular}{|l|c|c|}
\hline Grilled Sample-h & T-test & F-test \\
\hline Moisture & 0.000 & 0.1 \\
\hline Protein & 0.000 & 0.2 \\
\hline Fat & 0.000 & 0.6 \\
\hline Ash & 0.000 & 0.0 \\
\hline CHO & 0.000 & 0.0 \\
\hline
\end{tabular}

\begin{tabular}{|l|c|c|}
\hline Grilled Cooked Sample-b & T-test & F-test \\
\hline Moisture & 0.000 & 0.0 \\
\hline Protein & 0.000 & 0.0 \\
\hline Fat & 0.000 & 0.0 \\
\hline Ash & 0.000 & 0.0 \\
\hline CHO & 0.000 & 0.0 \\
\hline
\end{tabular}

\begin{tabular}{|l|c|c|}
\hline Grilled Cooked Sample-v & T-test & F-test \\
\hline Moisture & 0.000 & 0.1 \\
\hline Protein & 0.000 & 0.5 \\
\hline Fat & 0.000 & 0.0 \\
\hline Ash & 0.000 & 0.0 \\
\hline CHO & 0.000 & 0.0 \\
\hline
\end{tabular}

\begin{tabular}{|l|c|c|}
\hline Grilled Cooked Sample-t & T-test & F-test \\
\hline Moisture & 0.000 & 0.0 \\
\hline Protein & 0.000 & 0.3 \\
\hline Fat & 0.000 & 0.0 \\
\hline Ash & 0.000 & 0.0 \\
\hline CHO & 0.000 & 0.0 \\
\hline
\end{tabular}

\subsection{Fatty Acid Composition of the Pangasius Fillets}

The fatty acid composition, as well as lipid quantities, can be affected by the use of heat treatment to change the fat content of the fillets by using different heat treatments such as the microwave, steam and boiling depending upon the size of the meat, heat surface area, nature of the fish species and the heat temperature and it was reported by Gall et al., 1983. The fat content, mainly SFA and MUFA, is affected by the microwave cooked method and it is established by Pikul and Wojciechowska, 1994, and Kolakowska and Bienkiewicz, 1999. It was reported that the heat treatment causes the increase or decrease of the fat content. The composition of the fatty acid such as the SFA, MUFA and PUFA in the raw, steam and microwave- $47.15 \%, 46.73 \%$ and $46.91 \%$ respectively. The heat treatment affected the fat content of the SFA and it was changed from $47.15 \%$ to $46.93 \%$, in the case of treated samples, the reduction in the content of the saturated and monounsaturated fatty acid is increased or decreased to more than one percent after heat treatment. The MUFA content is constituted within the range of up to $40.41 \%$ to $41.00 \%$, in this result, the fatty acid composition changed by the treatment to up to $0.59 \%$ was reported. The PUFA content is increased after heat treatment and constituted the range of up to $12.45 \%$ to $12.53 \%$ respectively. in the present study, the defatted Pangasius fish fillets constituted more amount of saturated and mono-unsaturated fatty acid and it is reduced by the use of the different heat treatment such as the microwave, steam and grilled and present microwave cooking method it could be used to change or affect the SFA, MUFA and PUFA content of the fatty acid in the raw and the cooked meat. In the present research purpose, the removal of the saturated and mono unsaturated fatty acid can be used to cause heart disease and affect the market fetching rate. 
The present research proposed to defattening of Pangasius fillets were used by under grill oven at maintaining the temperature $120^{\circ} \mathrm{C}$ for 15 minutes. After heat treatment, the SFA and MUFA content was reduced and mineral composition was increased. The proximate composition was increasing the protein and ash while decreasing the moisture and fat content. Raw Pangasius meat contains head portion of saturated fatty acid-53.04\%, mono-unsaturated fatty acid-40.7\% and poly-unsaturated fatty acid-7.06\%. Body portion of saturated fatty acid-51.77\%, mono-unsaturated fatty acid-40.44\% and poly-unsaturated fatty acid- $7.06 \%$. Ventral portion of saturated fatty acid-50.37\%, mono-unsaturated fatty acid- $40.47 \%$ and poly-unsaturated fatty acid-7.07\%. Tail portion of saturated fatty acid-46.79\%, mono-unsaturated fatty acid-39.83\% and poly-unsaturated fatty acid-6.94\%. Grilled heat treatment was used to reduce saturated and mono-unsaturated fatty acids and retention of poly-unsaturated fats after defatted meats

Table 2: Fatty Acid Composition of Pangasius Meat

\begin{tabular}{|c|c|c|c|c|c|}
\hline Compounds & Fatty Acids & Head Portion & Body Portion & Ventral Portion & Tail Portion \\
\hline C 4:0 & Butyric acid & 0.13 & 0.12 & 0.10 & 0.11 \\
\hline C 12:0 & Lauric acid & 0.14 & 0.11 & 0.13 & 0.15 \\
\hline C 14:0 & Myristic acid & 4.42 & 4.45 & 4.41 & 4.47 \\
\hline C 14:1 & Myristoleic acid & 0.06 & 0.04 & 0.07 & 0.05 \\
\hline C 15:0 & Pentadecanoic acid & 0.40 & 0.42 & 0.44 & 0.43 \\
\hline C 15:1 & Cis-10 Pentadecanoic acid & 0.24 & 0.21 & 0.23 & 0.26 \\
\hline C 16:0 & Palmitic acid & 29.45 & 29.56 & 29.34 & 29.83 \\
\hline C 16:1 & Palmitoleic acid & 1.61 & 1.63 & 1.60 & 1.65 \\
\hline C 17:0 & Heptadecanoic acid & 0.43 & 0.41 & 0.44 & 0.42 \\
\hline C 17:1 & Cis-10 Heptadecanoic acid & 0.14 & 0.16 & 0.13 & 0.15 \\
\hline C 18:0 & Stearic acid & 8.18 & 8.27 & 8.53 & 8.25 \\
\hline C 18:1t & Vaccenic acid & 35.13 & 35.27 & 35.54 & 35.35 \\
\hline C $18: 2 \mathrm{t}$ & Linolelaidic acid & 5.17 & 5.24 & 5.43 & 5.27 \\
\hline C 18: $2 \mathrm{n} 6 \mathrm{c}$ & Linoleic acid & 0.14 & 0.13 & 0.15 & 0.12 \\
\hline C 18:3n3 & $\alpha$-Linolenic acid & 0.85 & 0.82 & 0.80 & 0.83 \\
\hline C 13:3 n6 & $\Upsilon$-Linolenic acid & 0.15 & 0.14 & 0.13 & 0.16 \\
\hline C 20:1 & Cis-11 Eicosenoic acid & 0.62 & 0.60 & 0.64 & 0.63 \\
\hline C 20:2 & Eicosadienoic acid & 0.54 & 0.52 & 0.50 & 0.54 \\
\hline C 20:4n6 & Arachidonic acid & 0.41 & 0.44 & 0.46 & 0.43 \\
\hline C 20:3 & Dihomo- $\gamma$-linolenic acid & 0.19 & 0.17 & 0.18 & 0.15 \\
\hline C 21:0 & Henicosanoic acid & 0.55 & 0.53 & 0.52 & 0.51 \\
\hline C 22:0 & Behenic acid & 1.31 & 1.35 & 1.33 & 1.32 \\
\hline C $22: \ln 9$ & Erucic acid & 0.54 & 0.51 & 0.55 & 0.53 \\
\hline C 22:2 & Docosadienoic acid & 0.03 & 0.04 & 0.02 & 0.01 \\
\hline C 22:6n3 & Docosahexanoic acid & 0.24 & 0.26 & 0.28 & 0.23 \\
\hline C 23:0 & Tricosanoic acid & 0.1 & 0.3 & 0.5 & 0.2 \\
\hline C 24:0 & Lignoceric acid & 0.42 & 0.41 & 0.40 & 0.44 \\
\hline C 24:1 & Nervonic acid & 0.86 & 0.84 & 0.87 & 0.83 \\
\hline \multicolumn{2}{|r|}{ Unknown } & 7.55 & 7.05 & 6.28 & 6.68 \\
\hline \multicolumn{2}{|r|}{ Total } & 100 & 100 & 100 & 100 \\
\hline
\end{tabular}

\begin{tabular}{|l|c|c|c|c|}
\hline \multicolumn{1}{|c|}{ Samples } & Grilled Head Portion & $\begin{array}{c}\text { Grilled Body } \\
\text { Portion }\end{array}$ & Grilled Ventral Portion & $\begin{array}{c}\text { Grilled Tail } \\
\text { Portion }\end{array}$ \\
\hline Saturated fatty acids & 45.53 & 45.93 & 46.14 & 46.13 \\
\hline $\begin{array}{l}\text { Mono-unsaturated fatty } \\
\text { acids }\end{array}$ & 39.20 & 39.26 & 39.63 & 39.45 \\
\hline $\begin{array}{l}\text { Poly-unsaturated fatty } \\
\text { acids }\end{array}$ & 7.72 & 7.76 & 7.95 & 7.74 \\
\hline
\end{tabular}




\subsection{Minerals Composition of Pangasius Fillets}

Gokoglu et.al., 2004 reported the mineral composition of the raw and cooked meats of the fillets. It is established that the sodium content of the raw fillets is $501.5 \mathrm{mg} / \mathrm{kg}$ and for the microwave and fried fish, it is not significantly changed.

The different heat treatment methods such as microwave method, grilled and the steam cooked method are followed. The mineral composition of the grilled cooked fillets to be found less and after heat treatment there is an increase in the mineral composition such as the $\mathrm{Na}, \mathrm{P}, \mathrm{Fe}, \mathrm{Ca}, \mathrm{Mg}$ and $\mathrm{Zn}$ studied in the fish fillets. The sodium content of the grilled cooked head portion to be found in the range of $1654 \mathrm{ppm}$ and in tail portion of meat content, it is $1632 \mathrm{ppm}$. The phosphorous content of the head portion of fillets is $4112 \mathrm{ppm}$ and in tail meat, it is $4132 \mathrm{ppm}$. The iron content of the head portion of fillets is found to be in the range of $48 \mathrm{ppm}$ and in body meat, it is $44 \mathrm{ppm}$. The zinc content of the head portion of fillets is found to be in range of $577 \mathrm{ppm}$ and in tail meat it is of $571 \mathrm{ppm}$.

The calcium content of the head portion fillets to be found to be in the range of $2571 \mathrm{ppm}$ and in tail meat it is of $2675 \mathrm{ppm}$. The magnesium content of the head portion is found to be in the range of $272 \mathrm{ppm}$ and in ventral portion it is of $276 \mathrm{ppm}$. It can be explained that the minerals composition of both, it can be either increased or decreased after heat treatment. After heat treatment, the mineral composition in raw fillet is increased and in cooked fillet it is increased gradually.

Table 3: Minerals Composition of Pangasius Meat

\begin{tabular}{|l|c|c|c|c|c|c|}
\hline \multicolumn{1}{|c|}{ Samples } & $\begin{array}{c}\text { Phosphorous (P) } \\
\text { ppm }\end{array}$ & $\begin{array}{c}\text { Iron } \\
(\mathbf{F e}) \mathbf{p p m}\end{array}$ & $\begin{array}{c}\text { Zinc } \\
(\mathbf{Z n}) \mathbf{p p m}\end{array}$ & $\begin{array}{c}\text { Calcium } \\
(\mathbf{C a}) \mathbf{p p m}\end{array}$ & $\begin{array}{c}\text { Magnesium } \\
(\mathbf{M g}) \mathbf{p p m}\end{array}$ & $\begin{array}{c}\text { Sodium (Na) } \\
\mathbf{p p m}\end{array}$ \\
\hline Microwave-H meat & 4112 & 48 & 577 & 2571 & 272 & 1654 \\
\hline $\begin{array}{l}\text { Microwave-B cooked } \\
\text { meat }\end{array}$ & 4131 & 44 & 576 & 2578 & 274 & 1667 \\
\hline $\begin{array}{l}\text { Microwave-V cooked } \\
\text { meat }\end{array}$ & 4135 & 47 & 571 & 2572 & 276 & 1678 \\
\hline $\begin{array}{l}\text { Microwave-T cooked } \\
\text { meat }\end{array}$ & 4137 & 42 & 573 & 2675 & 275 & 1632 \\
\hline
\end{tabular}

\section{CONCLUSIONS}

The present research was carried out to study the nutritional composition of defattening of catfish (Pangassius hyphoththalmus) fillets. This study focused on the analysis of proximate, fatty acid and mineral composition from raw and grilled cooked fillets. Proximate composition gradually increased after heat treatment. Main composition was affected by moisture and fat content gradually decreased and ash and protein content increased after heat treatment. Fat composition of fillets was affected by heat treatment and it is mainly focused on the saturated and mono-unsaturated fatty acid composition and poly un-saturated fatty acid. After heat treatment, the defatted meat nutritional composition such as proximate composition moisture and fat content was gradually decreasing from the raw composition. Ash and protein content gradually increases after heat treatment. Saturated and mono-unsaturated fatty acid was affected by heat treatment this content gradually decreases from the raw composition and poly un-saturated fatty acid was increased after heat treatment. After heat treatment, SFA and MUFA content decreased and PUFA content was increased. Mineral composition gradually increased after heat treatment. 


\section{REFERENCES}

1. Jeyakumari, A., Janarthanan, eG., Chouksey, M.K. and Venkateshwarlu, G., 2016. Effect of fish oil encapsulates incorporation on the physico-chemical and sensory properties of cookies. Journal of food science and technology, 53(1), pp.856-863

2. Anar Bakieva, Mukhamedzhan Akimov, Galiya Abdilova, Nadir Ibragimov \& Gulvira Bekeshova, "Developing New type of Disk Plate for Meat Chopper and its Effect to Water-Binding Capacity and Yield Stress of Minced Meat”, International Journal of Mechanical and Production Engineering Research and Development (IJMPERD), Vol. 9, Issue 6,pp, 377-390

3. Long, N.V., Yang, Y., Thi, C.M., Van Minh, N., Cao, Y. and Nogami, M., 2013. The development of mixture, alloy, and coreshell nanocatalysts with nanomaterial supports for energy conversion in low-temperature fuel cells. Nano Energy, 2(5), pp.636-676.

4. Bolat Kabulov, Ayaulym Mustafayeva, Nazira Kuderinova,Samat, Kassymov, Mars Khayrullin, Artur Pavlov, Vladimir Ermolaev, Anastasia Kuzmina, Alla Vorobeva, "Effect of Mechanical Processing of Minced Meat on the Change of Yield Stress,',International Journal of Mechanical and Production Engineering Research and Development (IJMPERD), Vol. 9, Issue 5,pp, 333-342

5. Noseda, B., Islam, M.T., Eriksson, M., Heyndrickx, M., De Reu, K., Van Langenhove, H. and Devlieghere, F., 2012. Microbiological spoilage of vacuum and modified atmosphere packaged Vietnamese Pangasius hypophthalmus fillets. Food Microbiology, 30(2), pp.408-419.

6. Abdul Samad Mangsi, Muhammad Khaskheli, Aijaz, Hussain Soomro \& Muhammad Ghiasuddin Shah, "Antibiotic Residues Detection in Raw Beef Meat Sold for Human Consumption in Sindh, Pakistan ",IMPACT: International Journal of Research in Applied, Natural and Social Sciences (IMPACT: IJRANSS),Vol. 2, Issue 7,pp, 15-20

7. Domiszewski, Z., Bienkiewicz, G. and Plust, D., 2011. Effects of different heat treatments on lipid quality of striped catfish (Pangasius hypophthalmus). Acta Scientiarum Polonorum Technologia Alimentaria, 10(3).

8. Sabbineni Poojitha, “A Study on Problems Faced by Contract Broiler Poultry Farmers”, IMPACT: International Journal of Research in Humanities, Arts and Literature (IMPACT: IJRHAL),Vol. 6, Issue 11,pp, 111-116

9. Mahmoud, M.A., Chamanzar, M., Adibi, A. and El-Sayed, M.A., 2012. Effect of the dielectric constant of the surrounding medium and the substrate on the surface plasmon resonance spectrum and sensitivity factors of highly symmetric systems: silver nanocubes. Journal of the American Chemical Society, 134(14), pp.6434-6442.

10. AOAC, 2000 AOAC Official methods of analysis.

11. Kjeldahl, C., 1883. A new method for the determination of nitrogen in organic matter. Z Anal Chem, 22, p.366.

12. Folch, J., Lees, M. and Stanley, G.S., 1957. A simple method for the isolation and purification of total lipides from animal tissues. Journal of biological chemistry, 226(1), pp.497-509.

13. Marimuthu, K., Thilaga, M., Kathiresan, S., Xavier, R.H.M.H. and Mas, R.H.M.H., 2012. Effect of different cooking methods on proximate and mineral composition of striped snakehead fish (Channa striatus, Bloch). Journal of food science and technology, 49(3), pp.373-377.

14. Ersoy, B. and Özeren, A., 2009. The effect of cooking methods on mineral and vitamin contents of African catfish. Food Chemistry, 115(2), pp.419-422.

15. Gall, K.L., Otwell, W.S., Koburgier, J.A. and Appledorf, H., 1983. Effects of four cooking methods on the proximate, mineral and fatty acid composition of fish fillets. Journal of Food Science, 48(4), pp.1068-1074.

16. Pikul, J. and Wojciechowska, K., 1994. Effect of coating and immersed frying of chicken carcasses on a lipids oxidation 
Analysis of Proximate, Fatty Acid and Mineral Composition

during cold storage. Gospodarka Miesna (Poland).

17. Kolakowska, A. and Bienkiewicz, G., 1999. Stability of fish lipids during microwave heating. Acta Ichthyologica et Piscatoria, 1(29), pp.101-111.

18. Gokoglu, N., Yerlikaya, P. and Cengiz, E., 2004. Effects of cooking methods on the proximate composition and mineral contents of rainbow trout (Oncorhynchus mykiss). Food Chemistry, 84(1), 19-22. Merrill, A.L. and Watt, B.K., 1973. Energy value of foods: Basis and derivation (agriculture handbook no. 74). Washington: US government printing office. 
